Please cite this article as:

de Paulo, A. F., Nunes, B., \& Porto, G. (2020). Emerging green technologies for vehicle propulsion systems. Technological Forecasting and Social Change. https://doi.org/10.1016/j.techfore.2020.120054

\title{
Emerging green technologies for vehicle propulsion systems
}

\author{
Alex Fabianne de Paulo ${ }^{1}$ (Corresponding author) \\ Breno Nunes ${ }^{2}$ \\ Geciane Porto ${ }^{3}$
}

\section{Introduction}

The climate change caused by greenhouse gases emissions in the atmosphere has been widely discussed for years. The transport area is one of the largest contributors for this scenario accounting for $23 \%$ of total $\mathrm{CO}_{2}$ emissions. This is because $95 \%$ of the energy used in transport comes from fossil fuels (Sims et al., 2014). Globally, transport is likely to continue being a big source of pollution, particularly urban air pollution. While the mobility by car is forecast to only grow $32 \%$ by 2050 in OECD countries; it will raise by a staggering $185 \%$ in non-OECD countries (ITF, 2017). If initiatives are not taken to find and use alternative and non-polluting energy sources at a reasonable cost, this demand may further jeopardize the planet's environmental conditions (IPCC, 2014a, Creutzig et al., 2015). Numerous treaties have already been proposed at global level to establish policies that foster clean technology initiatives and mitigate environmental impacts. Paris Agreement is the most recent one (UNFCCC, 2015). New legislation is coming in place to ban the sales of new petrol and diesel vehicles in countries like Denmark, Germany, France, and United Kingdom by 2040. Burch and Gilchrist (2018) also point out the list of actions from dozens of other countries to phase-out the production of combustion vehicles as well as the incentive to adopt EVs (electric vehicles). Despite the rapid evolution in the development of EVs, technological learning for the transition to a low carbon transport system still has challenges that depend on innovations in energy storage technologies such as batteries as well as at infrastructural and policy level, i.e. better plan for electric grid infrastructure (Kittner et al., 2020).

Clean energy generation through renewable sources, among them solar, wind, water or biomass is also a key step to reduce greenhouse gas emissions. Hydrogen has been pointed out as an alternative (Johnston et al. 2005) however its commercial application (e.g. full cells) are still growing slowly. In particular, solar and wind power have been subject of increasing research (IEA, 2016a, IEA, 2016b; Hussain, Arif and Aslam, 2017). It is estimated that between 2015 and 2040 global power generation capacity will more than double, from $6,418 \mathrm{GW}$ to $13,46 \mathrm{GW}$, with solar and wind sources representing $11 \%$ of this capacity in 2015 and they will represent 52\% of clean energy generation in 2040 (Bloomberg, 2016).

Despite the recent advance in understanding, designing and implementing green technologies for energy generation, some of these technologies are not widely explored to be used directly in vehicle propulsion systems. This is the case for solar and wind power ${ }^{4}$. In this

\footnotetext{
${ }^{1}$ School of Economics, Business Administration and Accounting at Ribeirão Preto, University of São Paulo Bandeirantes Avenue, 3900, Room 42 - Building B2, 14040-905 - Ribeirão Preto, State of São Paulo, Brazil. Email: alex.fabianne@gmail.com

${ }^{2}$ Aston Business School, Aston University, Birmingham, UK, B4 7ET, E-mail: b.nunes@aston.ac.uk

${ }^{3}$ School of Economics, Business Administration and Accounting at Ribeirão Preto, University of São Paulo Bandeirantes Avenue, 3900, Room 42 - Building B2, 14040-905 - Ribeirão Preto, State of São Paulo, Brazil E-mail: geciane@usp.br

${ }^{4}$ The IPCs classified in Green Inventory are common to solar and wind energy sources and therefore the analyses and results embrace vehicle propulsion technologies generated by sun or wind.
} 
paper, we define such use of green technologies to vehicle propulsion systems as Green Vehicle Propulsion (GVP). GVP is very important in vehicles, especially EVs. It can automatically provide additional energy to power when the car is parked or moving, which may reduce the reliance on energy from the power grid as well as reducing the charging time. Some studies analyze technology evolution on GVP and point out their trends based on empirical knowledge and expert opinion (Wang, $\mathrm{Yu}$ and Zhu, 2008; El-Refaie, 2013, Kumar and Jain, 2014; Williamson, Rathore and Musavi, 2015). However, it is observed that trends analysis on GVP based on knowledge flow are not commonly used, especially when they come from patent data, thus missing an opportunity to aggregate value in the understanding of future trends. This must be considered because relevant technological information is described in granted patents that cover several knowledge areas and are reliable sources of technological innovations (Blackman, 1995; Ardito et al. 2018; Pereira et al., 2019; Eilers et al., 2019).

Thus, this paper investigates the GVP technological paths, points out the characteristics of main GVP innovations, and indicates the most emerging green technologies for vehicle propulsion systems. The study was done based on solar and wind patents for vehicle propulsion applied between 1990 and 2016 in main world patent offices. Patents have been widely used for studies of competitive technological intelligence to identify emerging innovations and to assist organizations, especially R\&D field, with strategic information for decision making. In addition to pointing out technological innovations, patents have advantages of covering several technological fields, not having duplicate scientific data and, they are classified in a coherent way that gives greater credibility to this type of data source. This paper contributes to the theory and practice of GVP technologies by evaluating the relationships between different technologies using Social Network Analysis (SNA).

The identification of emerging technologies from patents is one of the main points when discussing technological forecasting. This activity is essential for Research and Development (R\&D) management of companies and portfolio management of scientific research, as well as for definition of policies to support and encourage innovation. This paper addresses three main research questions:

(i) What is the relationship between the first country of patent application and the other markets within the commercial interest of GVP inventors?

(ii) How can the main developers of GVP systems be classified?

(iii) What are the most promising and emerging green technologies used in vehicle propulsion systems?

In general, studies on technological trends, discuss almost exclusively technological issues, leaving a gap of analysis regarding other variables such as technologies' assignees or interest markets. The three research questions are complementary to each other and aim to provide answers to topics of interest to R\&D managers and researchers in the area. Based on the gaps in the literature about technological trends, they will provide information and analysis as part of technological competitive intelligence. So, this paper was based on, and complements, the forecasting theory proposed by Verspagen (2007). It was designed to explore issues intrinsic to technological prospecting, addressing aspects related to the actors of the inventions and technological field evolution.

The paper is structured as follows: after this brief introduction, the next section will present the literature review about GVP and then the methods for analyzing technological routes. Next, the procedures for data collection and analysis are presented, followed by results and findings. Finally, the conclusions section completes the paper. The results will supplement experts' opinion or point out further unexploited GVP analyses as well as collaborate with industry on relevant information of vehicle area. 


\section{Green technologies for vehicle propulsion systems}

This section presents the relevant literature on green technologies for vehicle propulsion systems. A review of publications on the green technology adoption shows the researchers' concern to break economic barriers. Previous research shows the economic-technological viability and proposes policy changes to foster the adoption of green technologies such as solar and wind power (Solangi et al., 2011; Hochstetler and Kostka, 2015; Yu et al., 2016).

Solar and wind energy sources applied to transport sector have been widely studied (Patel, 2005; Lund and Kempton, 2008; Hau, 2013). Most of these GVP studies discuss advantages, strategies, and applications related to EVs or Hybrid EVs (Richardson, 2013; Yong et al., 2015), green charging stations, batteries and devices adapted to convert solar radiation into electrical energy (Wang et al., 2011; Patterson, Macia and Kannan, 2015), power supplies from solar/wind (Nema, Nema and Rangnekar, 2009; Zhou et al., 2010) and propulsion of vehicles (WIPO, 2017). Specifically, about propulsion of vehicles, Rajashekara (2013) defines this type of technology as being a critical subsystem responsible for providing the traction effort that drives the vehicle. In EVs, propulsion system consists of power converter, and propulsion motor, and associated controllers.

Most of the studies on GVP technologies are related to EVs (Høyer, 2008; Kumar and Jain, 2014). In the early 1990s, Chan (1993) pointed to trends of AC (alternate current) motor units with converter and advanced power controller, as well as the use of batteries as the main units of energy storage for propulsion. Later, the same author included technologies that manage and control storage, traction and consumption strategy as the main drivers for EV future (Chan, 2007). Energy storage technology has also become one trend of hybrid electric vehicle propulsion sources. For instance, ultracapacitor packs can be used as power boosters in battery electric vehicles and as energy recovers in micro-hybrids (Wang et al., 2008; Miller, 2008). More recent research on vehicle propulsion systems point to technological trends aimed at: i) vehicle range; (ii) vehicle cost; iii) cost of battery replacing; iv) battery pack life and v) quick and easy recharging. Except for vehicle cost, most of development work of the propulsion system highlights battery systems as technological ones to emerge in this area (Rajashekara, 2013; Kumar and Jain, 2014; Williamson, Rathore and Musavi, 2015).

However, there is no specific study pointing out what countries or companies are further ahead of GVP technologies. Furthermore, discussions about major GVP innovations and their developers are also uncommon and, sometimes, targeted to manufacturers and their subsidiaries. For instance, El-Refaie (2013) and Rajashekara (2013) discuss vehicle propulsion technologies developed by Honda Motor, Toyota Motor, General Motors, Ford, Nissan and Tesla. Therefore, there are opportunities for complementary patent-based analysis to highlight key trends in GVP technologies and this will be done in this paper.

The decisions on the use of SNA as the main method for analyzing the technology routes of GVP is explained next through a comparative analysis of different methods.

\section{Review of methods for technological forecasting based on patent analysis}

The identification of emerging technologies and new knowledge fields has become essential for researchers, policy makers and industry itself (Prabhakaran, Lathabai and Changat, 2015). For this, patents and citations analysis have been used as an important data source to identify promising inventions in different technological areas (Kuhn, 2012). This type of analysis can be a powerful tool for identifying technological trends.

There are different methods of technological forecasting based on patent analysis and they have different strengths and limitations (table 1). We analyzed the main methods used in the 
literature, we verified that: (i) cross-impact matrix can be used when it is desired to identify the interrelations between different technological fields, as long as they are not very wide; (ii) $k$ core analysis is more appropriated to identify trends in a micro level using both past and current references in a limited dataset; (iii) pagerank is one of the most recent algorithm used to predict relevant technology and it can be indicated when it necessary just point the trend without an evolutionary or temporal analysis; (iv) multi criteria is a common technique when it is necessary evaluate different technology issues to point a trend, but it demand a very robust computational infrastructure; (v) SPLC is appropriate when it is desired to carry out large variations in technological fields in order to identify emerging technologies, providing an map technology evolutionary as well as it allow easily point out the most relevant technologies. The SPLC algorithm was chosen because it was considered stronger (more robust) than other methods, and its limitations can be more easily mitigated. More details about it will be explored on next paragraphs.

Table 1 - Main methods of technological forecasting based on patent analysis

\begin{tabular}{|c|c|c|c|}
\hline Method & Strengths & Limitations & Sources \\
\hline $\begin{array}{l}\text { Cross- } \\
\text { impact } \\
\text { matrix } \\
\text { CIM }\end{array}$ & $\begin{array}{l}\text { - It uses the criterion of patent co- } \\
\text { classification instead of patent co- } \\
\text { citation } \\
\text { - Multiple classification of patents } \\
\text { is used to evaluate the } \\
\text { relationships between } \\
\text { technologies. }\end{array}$ & $\begin{array}{l}\text { - Macro view of technology area } \\
\text { - Limitations both in analysis and } \\
\text { arrays generated size } \\
\text { - Difficult to define and measure } \\
\text { the emergence of technology } \\
\text { (micro level) } \\
\text { - It is unable to assess the dynamics } \\
\text { that involve technological } \\
\text { development }\end{array}$ & $\begin{array}{l}\text { Choi, Kim and } \\
\text { Park (2007); } \\
\text { Kim et al., } \\
\text { (2011) }\end{array}$ \\
\hline $\begin{array}{l}K \text {-core } \\
\text { analysis } \\
\text { and trend } \\
\text { modeling }\end{array}$ & $\begin{array}{l}\text { - Systematic tool based on patent- } \\
\text { development paths } \\
\text { - Combination of ex-post and ex- } \\
\text { ante citation analyses } \\
\text { - It can forecast technological } \\
\text { developments at the micro level }\end{array}$ & $\begin{array}{l}\text { - Information can be lost during } \\
\text { analysis } \\
\text { - Algorithm neglects smaller paths } \\
\text { in network. } \\
\text { - A limitation on the number of } \\
\text { patents that can be analyzed }\end{array}$ & $\begin{array}{l}\text { Momeni and } \\
\text { Rost (2016) }\end{array}$ \\
\hline $\begin{array}{l}\text { Pagerank } \\
\text { algorithm }\end{array}$ & $\begin{array}{l}\text { - Evaluates citations dynamics from } \\
\text { different classes of patents } \\
\text { "backward" citations } \\
\text { - Dynamics of citations coming } \\
\text { from the different "precursor" } \\
\text { classes illuminates the mechanism } \\
\text { of the emergence of new fields }\end{array}$ & $\begin{array}{l}\text { - It does not give an evolutionary or } \\
\text { technological chain view } \\
\text { - Additional information is not } \\
\text { exploited }\end{array}$ & $\begin{array}{l}\text { Bruck et al. } \\
(2016)\end{array}$ \\
\hline $\begin{array}{l}\text { Multi- } \\
\text { criteria } \\
\text { method }\end{array}$ & $\begin{array}{l}\text { - Four criteria are considered: } \\
\text { technology life cycle, technology } \\
\text { diffusion speed, patent power, and } \\
\text { patent expansion } \\
\text { - Multi criteria view allows for a } \\
\text { more comprehensive analysis of } \\
\text { technology }\end{array}$ & $\begin{array}{l}\text { - It has serious limitations in using } \\
\text { only patent title data } \\
\text { - Provides a macro-level analysis } \\
\text { by IPC } \\
\text { - Complexity and computational } \\
\text { effort to manipulate citations and } \\
\text { patent codes. }\end{array}$ & $\begin{array}{l}\text { Altuntas, } \\
\text { Dereli and } \\
\text { Kusiak (2015) }\end{array}$ \\
\hline $\begin{array}{l}\text { Search path } \\
\text { link count } \\
(\text { SPLC) }\end{array}$ & $\begin{array}{l}\text { - Based on the analysis of the most } \\
\text { relevant connections } \\
\text { - Map the trajectory of the most } \\
\text { relevant technologies } \\
\text { - It points out the most emergent } \\
\text { and promising patent (micro } \\
\text { level) } \\
\text { - It provides a visual diagram of } \\
\text { technology route }\end{array}$ & $\begin{array}{l}\text { - Large number of citations may } \\
\text { require strong computational } \\
\text { capacity } \\
\text { - It is necessary to limit scope by } \\
\text { technological area to get better } \\
\text { routes and the most promising } \\
\text { technologies. }\end{array}$ & $\begin{array}{l}\text { Hummon and } \\
\text { Doreian } \\
\text { (1989); } \\
\text { Verspagen } \\
\text { (2007); } \\
\text { Fontana, } \\
\text { Nuvolari and } \\
\text { Verspagen } \\
\text { (2009) }\end{array}$ \\
\hline
\end{tabular}


The SPLC is based on a directed patents network that, when placed in an ordered sequence, points to different technological routes. Based on previous research provided by Hummon and Doreian (1989) which mapped scientific routes, Verspagen (2007) proposed a methodology that uses social network analysis (SNA) and patent citation to identify better paths. It also points out the main technology routes and identifies technological trends. The SPLC algorithm counts the number of times an edge is used to connect a patent to final patents of the network. Thus, scores are assigned to the edges in such a way that those with the highest score show the most relevant technological trajectory (Verspagen, 2007; Bekkers and Martinelli, 2012). This SPLC technique corresponds to the assignment of weight for each network edge (citation) based on the position of the general structure which in turn is based on the existence of different paths in the network. Thus, a path is a sequence of citations that extends from the most recent patent to the oldest one, passing through intermediate patents. This represents the flow of knowledge of a technology. The greater the number of paths that pass through an edge indicates a greater weight assigned by SPLC algorithm and more important will be that edge (Verspagen, 2007). For instance, in the case of a patent " $\mathrm{X}$ ", the more paths this patent connects to, it indicates that "X" will be a better representability in relation to the other patents and more importance it will have on the network, having the potential to be classified as an emerging technology.

Several studies and applications were developed based on SPLC to find and explore technological trajectories: identification of fuel cells paths (Verspagen, 2007), telecommunications industry technological paths and evolution (Martinelli, 2008), route mapping for data communication technologies (Fontana, Nuvolari and Verspagen, 2009), trajectories, patterns and strategies in high-tech markets (Bekkers and Martinelli, 2012), RFID and emerging technologies detection (Prabhakaran, Lathabai and Changat, 2015).

The present study joint SPLC and SNA to get the findings. So, it is also important to discuss about SNA as previously did with SPLC. The SNA has been used as an important visualization and analysis tool for trend identification, especially from patents data. It was chosen because it is a method that offers resources for both qualitative and quantitative analyses (Fontana, Nuvolari and Verspagen, 2008). SNA has applications in many knowledge fields such as social relationships, evaluation and traffic control for transport networks, web navigation analysis, and epidemic spread analysis (Chen et al., 2002; Keeling and Eames, 2005; Scott, 2017). When analyzed through a citation network approach, it can provide interesting results. Studies by Egghe and Rousseau (2002) on co-citation networks and collaborative networks produced by Batagelj and Cerinšek (2013) demonstrate the potential for relations analysis exploration based on SNA.

SPLC is a mathematical algorithm that calculates the most used paths and assists in defining the most relevant trajectories (Verspagen, 2007). SNA is a technique derived from the theory of graphs and which, in addition to the ease of understanding and interpretation of data provided by graphical visualization in the form of a network, has functions that enrich data analysis, such as those that point out the most centralized nodes or more influential in the network, for example. The combination in the use of SPLC and SNA brings the advantage of reconciling the identification of routes and emerging technologies with the characterization of nodes (patents) and interrelationship between them through the functions available in SNA (Fontana, Nuvolari and Verspagen, 2009).

In this paper uses the technique proposed by Verspagen (2007) to identify the main technological trajectory based on the SPLC algorithm. This author defines a technological trajectory as an evolutionary vision of parts of the knowledge contained in a patent document. More recently, Porto, Kannebley, and Baroni (2014) expands this definition to the Technological Route (TR) concept. They proposed a process to map a technological trajectory of a set of patents, understand knowledge flow, most relevant technology on the route and point out the emerging technologies. Thus, from the construction of patent citation networks, it is 
possible to identify the temporal evolution of a technology, through the various players who have developed technological contributions until the latest technologies, also called emerging technologies (Pereira and Porto, 2018; Pereira et al., 2019).

Regarding "emerging technologies", there are many visions to this term (Cozzens et al., 2010). Rotolo et al. (2015) delimits it as novelty, possibility of rapid growth, coherence, uncertainty and ambiguity. Song et al. (2018) complement this concept by pointing out that promising technologies have recently emerged with high uncertainty and possibility of market impact and growth. In this paper, we expand the original concept of emerging technology to the most promising and emerging technology (MPET). The latter includes those patents which are most recently applied, and which are in the top of the technological route (TR), and therefore with is a stronger probability of growth and market impact (Verspagen, 2007).

\section{Research Methodology}

For this study, only technologies classified in the 'International Patent Classification' belonging to the Green Inventory (IPC-GI) were selected. Thus, the scope of this research is limited to these two technological groups (IPCs B60K001600 and B60L000800) defined in IPC-GI and not to the wide concept of vehicle propulsion as defined by Rajashekara (2013). This is because technologies related to GVP, such as batteries and energy storage systems, are classified into other groups of IPCs and will be investigated in future studies. So, GVP technologies using solar or wind power were extracted from Derwent Innovation by Clarivate Analytics, a private patent database. It provides the most comprehensive collection of global patent data in more than 50 authorities and covering over 30 languages.

The methodology of this research (Figure 1) covers five steps. The first three steps extract and transform patent data. In step 1, patent data of IPCs B60K001600 and B60L000800 and application year between 1990 and 2016 were selected according to the following query: "(ICR $=(\mathrm{B} 60 \mathrm{~K} 001600) \mathrm{OR}$ ICR $=(\mathrm{B} 60 \mathrm{~L} 000800))$ AND $(\mathrm{AY}>=(1990)$ AND AY $<=(2016))$ ", where ICR is IPC Current field and AY refers to patent application year. Only earliest patents of each INPADOC (INternational PAtent DOCumentation) were selected in such a way to avoid redundant data for same invention. These fields were selected from the patent documents: Publication Number, IPC Current, Application Year, Publication Year, Application Country, Assignee - Standardized, Assignee - Original w/address, Cited Refs - Patent, INPADOC, Abstract and Claims. In this step, 4,312 patents were extracted from the original patents database. Next, in step 2, the data were further refined and 436 patents rejected by the patent office were removed from our sample. The cause of those rejections is usually because the patent application does not constitute a new technology or the assignees have not complied with the necessary registration procedures. On the other hand, the valid patents are all those under analysis or with the right of protection has already been granted. So, the final database has 3,876 patents. Third step, assignees' names were submitted to a standardization, since there are syntax variations for the same name patent assignee. We use OpenRefine, a free software used for messy data cleaning and transforming, to group and standardize common names (Verborgh and De Wilde, 2013). This step does not intend to exhaust all inconsistencies but will minimize them, especially for assignees' names that occur most frequently in database.

The next two steps are called Design and Analysis. Step 4 explored general statistics that allow to identify variations in distribution of patents by IPC, by application country, main assignees, and protected market, as well analyze historical evolution of patent applications. Step 5 was built citations networks, identify clusters, build technological routes (TR) and point out most promising and emerging technologies (MPET). All these tasks were performed using the Gephi tool, a free software used for SNA (Bastian, Heyymann and Jacomy, 2009). The MPET 
of each cluster were obtained using a SPLC plug-in. In this step, also were made sensitivity tests to calibrate parameters of SPLC algorithm and thus to get the best route for each technological group.

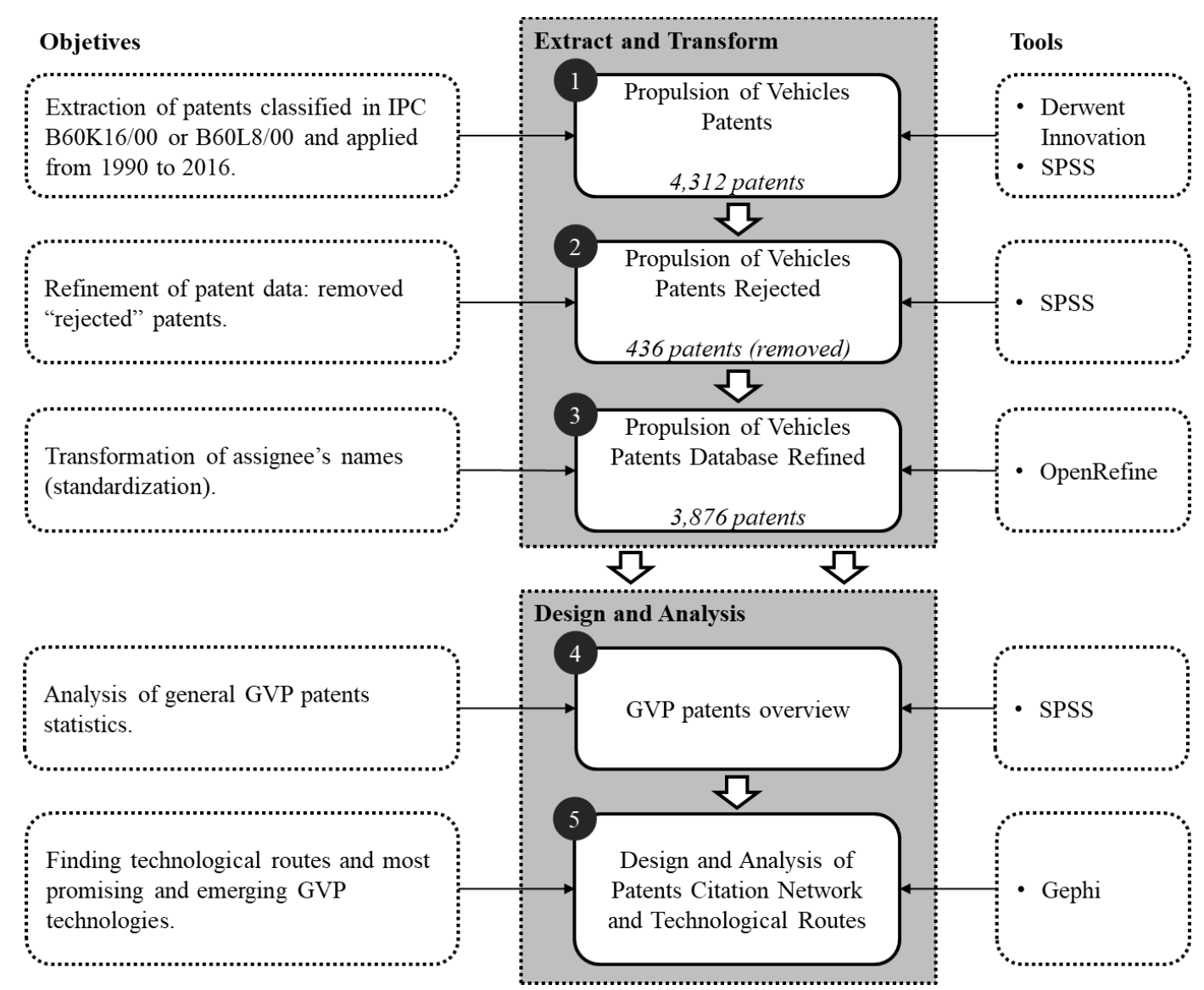

Fig. 1. Methodology synthesis

To provide the network analysis, some SNA functions such as modularity, giant component, betweenness and closeness centrality, weighted average degree, eigenvector centrality and edge betweenness were used to support the discussions. The Modularity function is used to group nodes that are more densely connected than the rest of the network. When it applies to a network, the colors indicate different communities and show nodes which are more interconnected with each other (Blondel et al., 2008). The Giant Component function represents the most connected part of a network that contains a significant proportion of all nodes in that network. When it is desired to analyze the relationship between the nodes, this function can be used to reduce the universe of analysis without compromising the results (Newman, 2010). The Betweenness Centrality points out the number of shortest paths of all nodes to all other nodes passing through a node X. This is a way of measuring the control potential that a node with high "intermediation" has to regulate the flow of resources among other nodes that it connects (Brandes, 2001; Newman, 2010). The Closeness Centrality function defines the average length of distances between one node and all other nodes in the network. It is a measure of reach, that is, the speed at which information can reach other nodes from a given initial node (Zhang, 2010). The Weighted Average Degree function shows the weighted average number of edges that are attached to a node (Newman, 2010). The Eigenvector Centrality is an additional function to find the most central nodes and those with the least distance from other ones. In general, Eigenvector Centrality considers the relevance of the edges rather than just looking at the amount or distance between them (Jackson, 2008). Finally, complementing the betweenness centrality function but now with focus on edges, Edge Betweenness is defined as the number 
of shortest paths that pass through an edge in a network (Newman, 2010). These functions allow a better understanding the relevance of each assignee in the whole networks as well as relationships and what their meanings.

\section{Results and Discussions}

This section presents the results and their respective discussions. First subsection explores an overview of GVP technologies that are analyzed IPC's and application countries distributions. It also presents an evolutionary view of patents applications as well as investigates main interest markets to technology protection and major assignees. Second subsection analyses whole GVP citation network, defines technology clusters and their relevance based on SNA statistics. In the third subsection, technological routes are investigated for each cluster and it is pointed out the most promising and emerging GVP technologies.

\subsection{Technology overview}

Since the research is based on IPCs B60L000800 and B60K001600 (Fig. 2), most of the technologies found are directly related to these classifications. Thus, most patents $(55 \%)$ have a classification linked to IPC B60L000800 which deals specifically with electric propulsion of vehicles. The IPC B60K001600 is only $20 \%$ of patents. These two IPCs have $12.8 \%$ patents assigned in both classifications. Although the scope of this study focuses on the two IPCs groups defined for GVP technologies, in a general way patents can be classified in additional technological fields simultaneously. So, other IPCs can be also presented here according to classification defined by patent assignee in such a way as to present possible fields related to GVP technologies. As patents may have several technology fields linked, there are still other IPCs highlighted here: B60L001118 and F03D000900. The first one is related to electric propulsion supplied from primary, secondary or fuel cells and occurs in $9 \%$ of GVP patents. The B60L IPC group encompasses related technologies "Propulsion of electrically-propelled vehicles". The second IPC with 4\% (F03D000900), refers to special adaptations of wind motors. It belongs to IPC about machines or engines for liquids; wind, spring, or weight motors; producing mechanical power or a reactive propulsive thrust, not otherwise provided for wind.

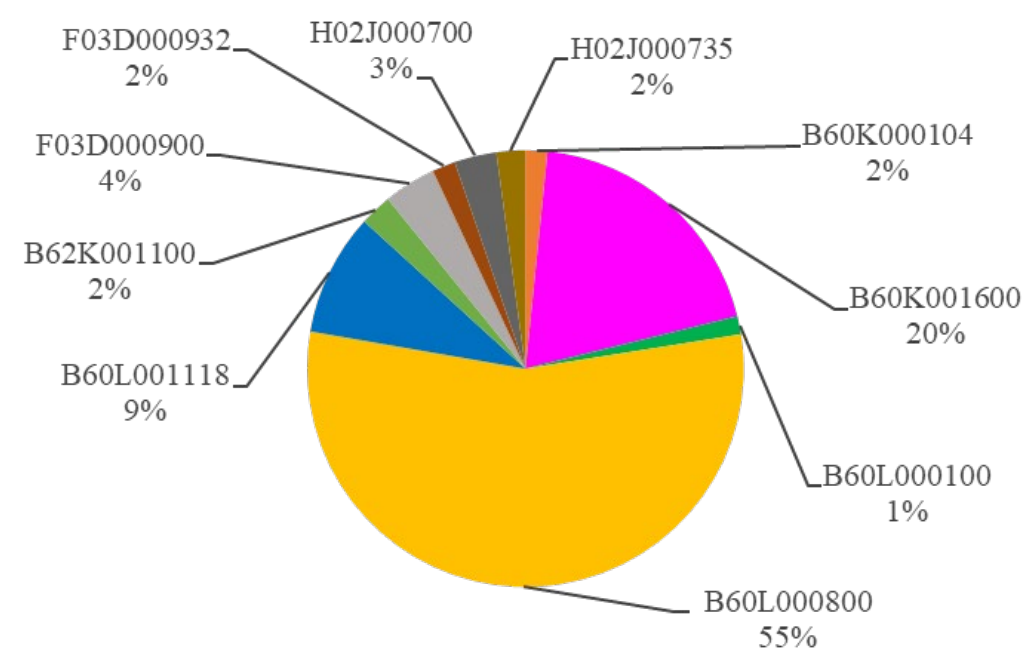

Fig. 2. Top 10 IPCs concentration from 1990 to 2016

Legend: B60K000104: Arrangement or mounting of electrical propulsion units of the electric storage means for propulsion 
B60K001600: Propulsion of vehicles using solar or wind power

B60L000100: Supplying electric power to auxiliary equipment of electrically-propelled vehicles

B60L000800: Electric propulsion of vehicles using solar or wind power

B60L001118: Electric propulsion with power supplied within the vehicle using power supplied from primary

cells, secondary cells, or fuel cells

B62K001100: Motorcycles, engine-assisted cycles or motor scooters with one or two wheels

F03D000900: Adaptations of wind motors for special use

F03D000932: Wind motors specially adapted for installation in particular locations on moving objects

H02J000700: Circuit arrangements for charging or depolarising batteries or for supplying loads from batteries

H02J000735: Parallel operation in networks using both storage and DC sources with light sensitive cells

The historical view of GVP innovations development is also another interesting point (figure 3). Since the early 1990s, industry has become more interested in electric propulsion technologies. In all years, more patents classified as B60L000800 occurred than B60K001600. In technology life cycle theory (Campbell, 1983; Haupt, Kloyer and Lange, 2007), this period corresponds to "initial phase" in which costs of R\&D are high and fundamental scientific and technological problems must be resolved. From 2004, a R\&D expanding phase is observed when GVP technologies starts to gather strength and theirs use has increased interest by manufacturers.. This period coincides with publications on the propulsion of electric vehicles (Chan, 1993; Chan, 2007). After 2009, there is a considerable increase in GVP patents application. This transition to growth phase of GVP technology life cycle also coincides with the boom of EVs and HEVs studies (Wang, Yu and Zhu, 2008; El-Refaie, 2013, Rajashekara, 2013), which is driven by discussions about global warming problems and reduced $\mathrm{CO}_{2}$ emissions. As studied by Lee and Berente (2013), even in the growth phase there will be incremental changes in the GVP technologies as this phase can be quite dynamic. In this way, additional innovations in GVP field must still occur in the next few years until reaching a phase of technological maturity. Still in figure 3, frequency of terms "solar" and "wind" can be observed in the claims of GVP patents. Term "solar" is observed in $45.8 \%$ of patents, "wind" $33.1 \%$ and "both" $21.1 \%$.

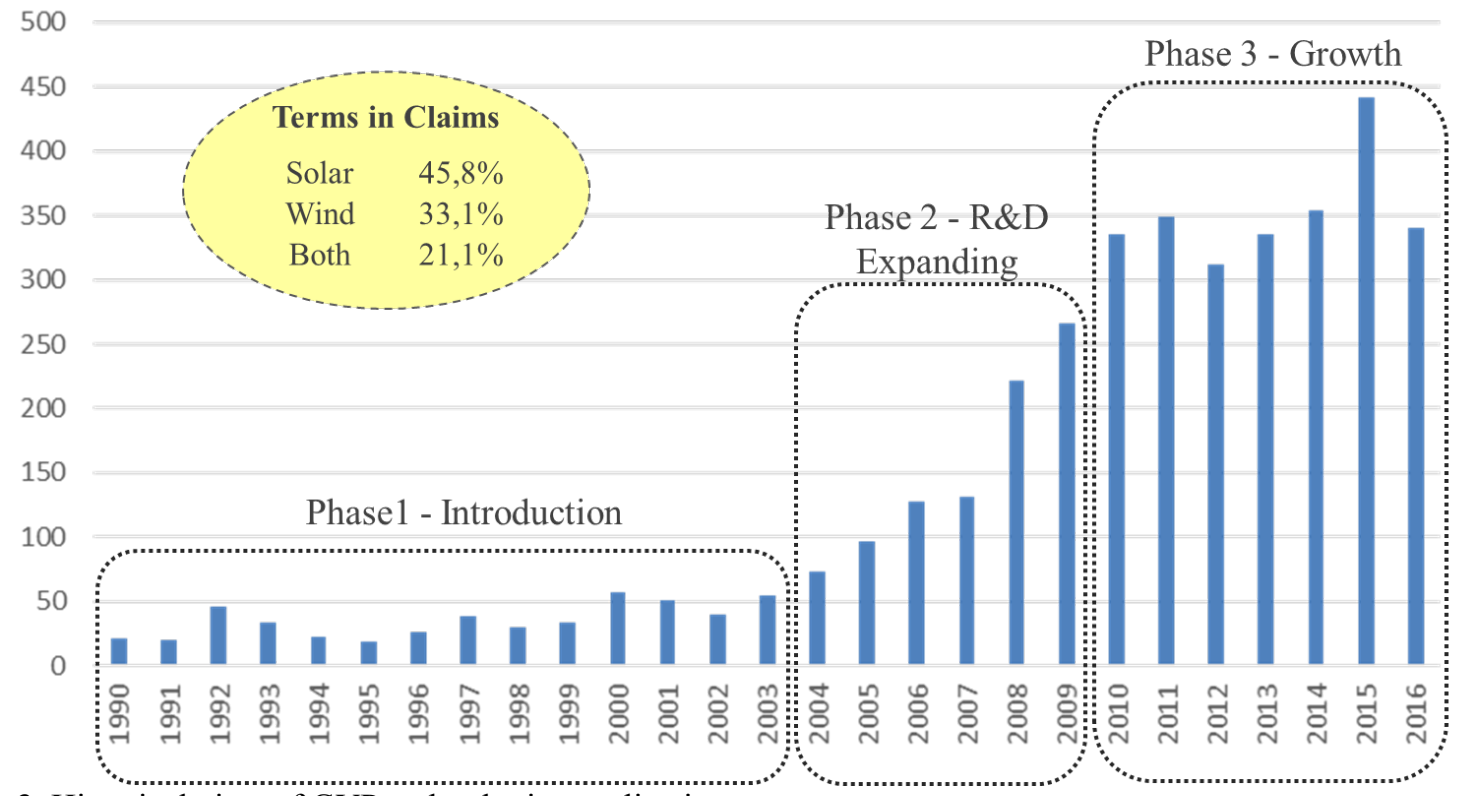

Fig. 3. Historical view of GVP technologies applications

Among the top 10 countries of patent offices (those with most GVP applications), applications in China are predominant as they receive almost $2 / 3$ of GVP first applications (figure 4). Indeed, China has been very committed to EV technology development (Zheng et 
al., 2015; Wu et al., 2017; Bohnsack, 2018). So, it was expected to find this type of technologies as part of the Chinese portfolio of technological innovation. An interesting point is that China has $74.4 \%$ of its patents applied after 2010 , which indicates a more recent effort in development of this technology type. Asian countries hold $76,6 \%$ of all GVP applications.

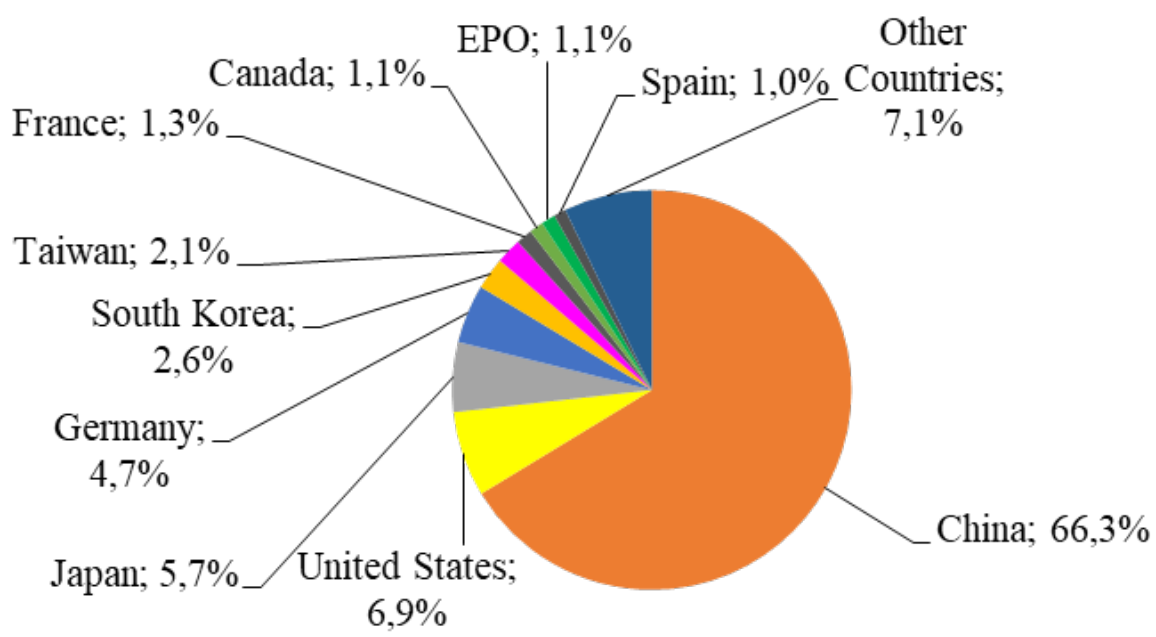

Fig. 4. Top 10 patent office's application

Complementing this analysis, table 2 shows the first application country of GVP patents, which are in fact the top 10 countries with most GVP applications, and other in which patents have been protected. Thus, green cells indicate a higher concentration of patents in that market, i.e. a proactive behavior for protecting the technology in your most important market. Yellows and orange indicate medium or low interest in technology protection respectively. Red cells indicate a lack of patents that means no interest in protecting technology in that country. The level of protection can vary from each year, i.e. a technology that was protected in only a few countries can be protected in new countries in the future, according to the potential of technology and demand in new markets.

Table 2 - Analysis of first application country

\begin{tabular}{|l|c|c|c|c|c|c|c|c|c|c|}
\cline { 2 - 12 } \multicolumn{1}{c|}{} & \multicolumn{9}{|c|}{ Interest of Market Protection } \\
\hline First Application Country & CA & CN & DE & EPO & ES & FR & JP & KR & TW & USA \\
\hline Canada (CA) & 0,340 & 0,083 & 0,028 & 0,083 & 0,014 & 0 & 0,076 & 0,028 & 0,035 & 0,313 \\
\hline China (CN) & 0 & 0,985 & 0,002 & 0,002 & 0 & 0 & 0,003 & 0,001 & 0 & 0,008 \\
\hline Germany (DE) & 0 & 0,004 & 0,910 & 0,027 & 0 & 0 & 0,018 & 0 & 0,009 & 0,031 \\
\hline European Patent Office (EPO) & 0,010 & 0,048 & 0,124 & 0,352 & 0,048 & 0,019 & 0,095 & 0,010 & 0 & 0,295 \\
\hline Spain (ES) & 0 & 0 & 0 & 0,049 & 0,902 & 0 & 0 & 0 & 0 & 0,049 \\
\hline France (FR) & 0 & 0 & 0 & 0,054 & 0 & 0,911 & 0 & 0 & 0 & 0,036 \\
\hline Japan (JP) & 0 & 0,027 & 0,015 & 0,019 & 0 & 0 & 0,871 & 0,008 & 0 & 0,061 \\
\hline South Korea (KR) & 0 & 0,026 & 0 & 0,009 & 0 & 0 & 0,009 & 0,922 & 0 & 0,035 \\
\hline Taiwan (TW) & 0 & 0 & 0 & 0 & 0 & 0 & 0 & 0 & 1,000 & 0 \\
\hline United States (USA) & 0,024 & 0,036 & 0,010 & 0,044 & 0,003 & 0 & 0,051 & 0,014 & 0,012 & 0,807 \\
\hline Total & 0,015 & 0,547 & 0,052 & 0,022 & 0,011 & 0,026 & 0,074 & 0,073 & 0,022 & 0,158 \\
\hline
\end{tabular}

First, the left-up to right-bottom diagonal line shows that there is major market protection in first countries of patents application. Second, columns with more green or yellow tones show main markets of interest (China, Germany, EPO, Japan and USA). Already reddish columns 
show markets of less interest (Canada, Spain, France, South Korea and Taiwan). Analyzing table 2, it is worth noting the cases of offices that had over $90 \%$ of patents applied only in the country of that office such as China (98.5\%), Germany (91\%), Spain $(90.2 \%)$, France $(90.1 \%)$, South Korea $(92.2 \%)$ and Taiwan $(100 \%)$. It is also important to point out that the patents whose assignees choose Canada and EPO as their first patent office, have a peculiar characteristic of being also widely protected in offices of other countries. In this way, $34 \%$ of patents first deposited in the Canadian patent office did not seek protection in the foreign market. This means that $66 \%$ of patents first deposited in Canada also sought protection in another of which $31.3 \%$ sought further protection in the USA.

Based on other papers that assume patent as a proxy for innovation (Altuntas et al., 2015; Burhan et al., 2017; Ardito et al., 2018), we developed a taxonomy inspired by the diffusion innovation approach of Rogers (2010). So, a new classification is proposed for these 15 major assignees according to their relevance in the development of GVP technologies throughout the analyzed periods. In this classification, two variables are evaluated: the period in which the patents were applied and the regularity of the deposits (figure 5).

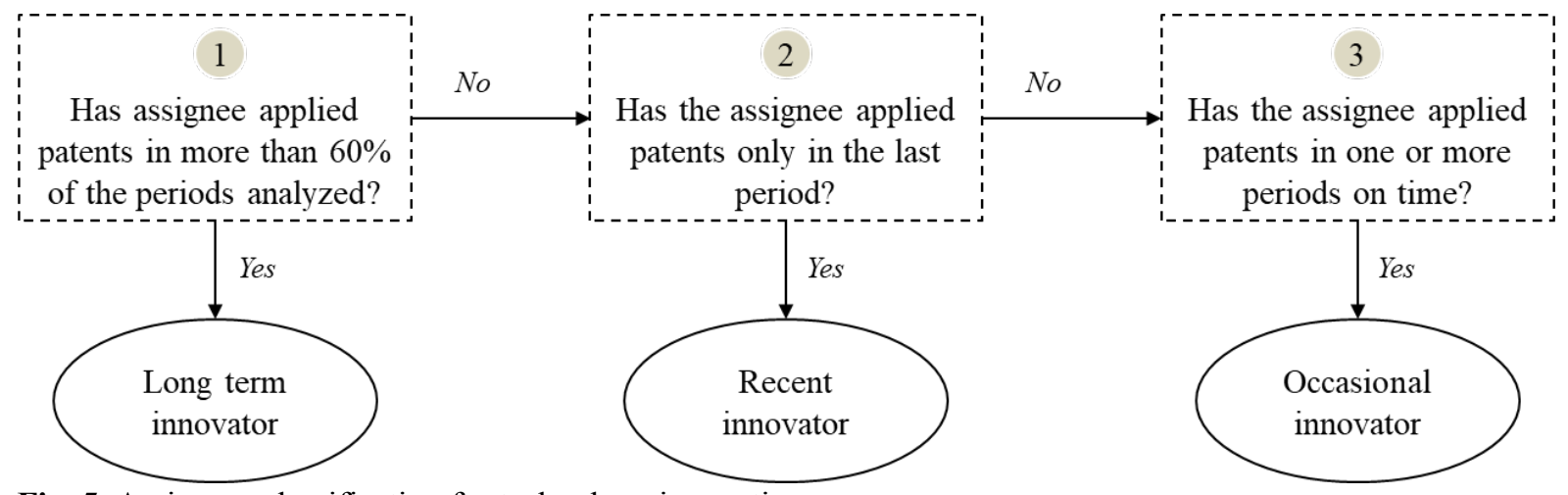

Fig. 5. Assignees classification for technology innovation

Regarding top assignees, table 3 shows the 15 assignees (firms), decreasingly ordered by total of patents and divided into six-year periods for the older patents, and five-year periods for applications most recent. According to table 3, it is noted that up to 2006, the amount of GVP patents is small and concentrated in three main assignees: Toyota, Hyundai and Honda. In addition to these companies, Nissan, Ford Global Tech and GM Global Technology Operations have also applied GVP patents for most of the periods. Thus, these six companies have been classified as "Long term innovator" since they have a high frequency of patent deposits over time. This fact demonstrates the long-term interest of these firms with innovations around GVP technologies. Although Toyota, Hyundai and Nissan have been continuing to invest more strongly in recent five years. The "Occasional innovator" classification is given to Peugeot Citroen, Jiangsu University, Pingdingshan Zhongjia and Kunming University, which invest eventually efforts in GVP patents development last 10 years. Last, the Wuxi Tongchun, Chongqing Yongchun, Tianjin Coslight, Huzhou Chari, Wuxi New Great, all Chinese firms, started developing GVP technologies after 2012 and are classified as "Recent innovator".

While assignees Peugeot Citroen, Pingdingshan Zhongjia and Honda have been committed to developing this type of technology up to 2011 but abandoned its interest from 2012. For GVP innovations, it can be observed that long term innovators are concentrated in Japan, United States and South Korea. On other hand, recent innovator are predominantly Chinese companies. This classification does not minimize the importance of Chinese companies to GVP technologies development. On the contrary, due to the intensity of efforts, investments and the speed with which the Chinese government and companies have given to the development of green technologies (Zhang and Gallagher, 2016; IEA, 2018; Gielen et al., 2019), it will most 
likely hold most of the know-how about GVP in the coming years, mainly due to the expected growth of the EV fleet (Li et al., 2016; IEA, 2019).

Table 3 - Ranking of Top 15 assignees

\begin{tabular}{|l|c|c|c|c|c|c|c|c|}
\hline \multicolumn{1}{|c|}{ AN } & AOC & TAC & TP & P1 & P2 & P3 & P4 & P5 \\
\hline Toyota Motor & Japan & Long term innovator & 39 & 2 & 2 & 2 & 7 & 26 \\
\hline Wuxi Tongchun New Energy Tech & China & Recent innovator & 15 & 0 & 0 & 0 & 0 & 15 \\
\hline Hyundai Motor & South Korea & Long term innovator & 14 & 3 & 3 & 0 & 1 & 7 \\
\hline Peugeot Citroen Automobiles & France & Occasional innovator & 13 & 0 & 0 & 0 & 13 & 0 \\
\hline Chongqing Yongchun New Energy Technology & China & Recent innovator & 11 & 0 & 0 & 0 & 0 & 11 \\
\hline Tianjin Coslight Auto Technology & China & Recent innovator & 10 & 0 & 0 & 0 & 0 & 10 \\
\hline Huzhou Chari Machinery \& Electrical Science & China & Recent innovator & 10 & 0 & 0 & 0 & 0 & 10 \\
\hline University Jiangsu & China & Occasional innovator & 9 & 0 & 0 & 1 & 0 & 8 \\
\hline Pingdingshan Zhongjia Energy Technology & China & Occasional innovator & 9 & 0 & 0 & 0 & 9 & 0 \\
\hline University Kunming Science \& Tech & China & Occasional innovator & 8 & 0 & 0 & 0 & 5 & 3 \\
\hline Nissan Motor & Japan & Long term innovator & 8 & 0 & 1 & 0 & 3 & 4 \\
\hline Ford Global Tech & United States & Long term innovator & 8 & 0 & 1 & 4 & 2 & 1 \\
\hline Wuxi New Great Power Electrical Machine & China & Recent innovator & 7 & 0 & 0 & 0 & 0 & 7 \\
\hline Honda Motor & Japan & Long term innovator & 7 & 1 & 4 & 1 & 1 & 0 \\
\hline GM Global Technology Operations & United States & Long term innovator & 7 & 0 & 0 & 4 & 1 & 2 \\
\hline
\end{tabular}

Legend: $\mathrm{AN}=$ Assignee name; $\mathrm{AOC}=$ Assignee original country; $\mathrm{TAC}=$ Technology adoption classification; $\mathrm{TP}=$ Total of Patents; $\mathrm{P} 1=1990$ to $1995 ; \mathrm{P} 2=1996$ to 2001; $\mathrm{P} 3=2002$ to $2006 ; \mathrm{P} 4=2007$ to $2011 ; \mathrm{P} 5=2012$ to 2016.

\subsection{GVP citation networks}

This section analyzes the citation networks for GVP technologies, identifies the most relevant technology clusters and the most influential patents according to the features and their relationships. For each network, nodes refer to patents and edges refer to links obtained through patent backward citations. Citation network has 6,765 nodes (patents) and 8,059 edges (backward citations). By applying the modularity function, it was observed 280 clusters (figure 6-a). To minimize network topology and to enable a better analysis, the giant component network was extracted, which consists of the largest interconnected network within the original network (figure 6-b). This reduced network "discards" isolated nodes from the network. In this case, the new citation network has 5,011 patents ( $74.1 \%$ of the initial network).

There are several relevant statistics in SNA which allow identifying the most interconnected nodes (closeness centrality, betweenness centrality, and average weighted degree) and relevant nodes that are connected to other important nodes (eigenvector centrality and edge betweenness). Top 10 clusters represent $47.1 \%$ of all network nodes and $49.9 \%$ of edges and their SNA statistics (table 4) were used to identify main three GVP communities. Marked in grey color are top statistics between analyzed clusters. Clusters with a better set of statistics (highest score) were considered as more relevant (bold names). The most relevant three clusters represent $16.7 \%$ of all network nodes and $24.3 \%$ of edges and main features of these clusters are described in Table 4 . The identification of the key citation network clusters allowed the examination of technological routes and finally the most promising and emerging technologies which will be described on next section. 


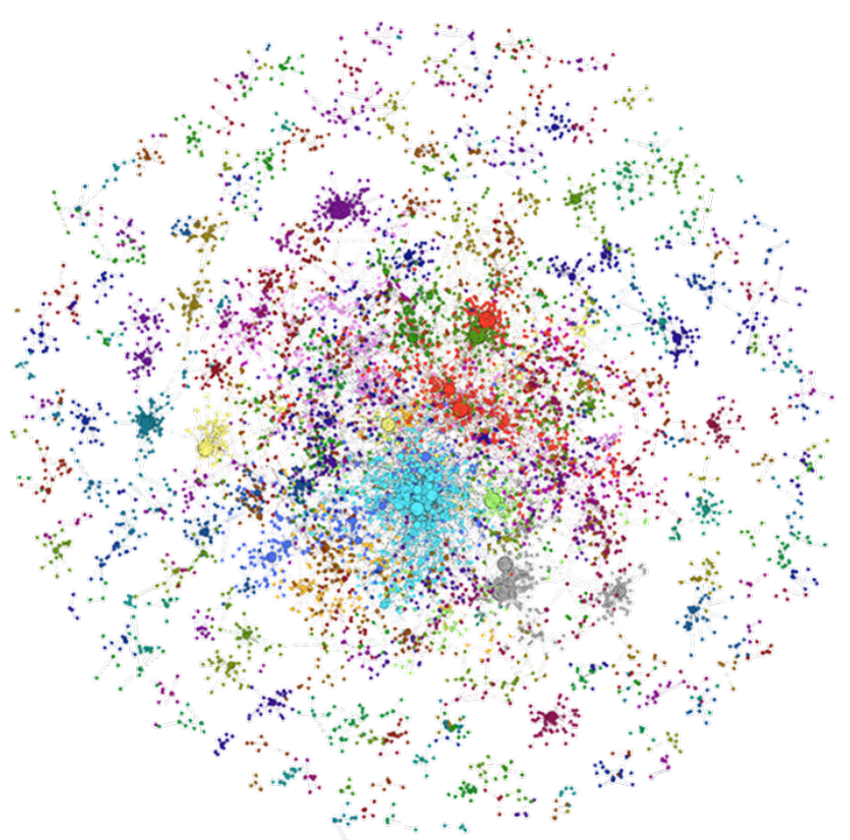

(a)

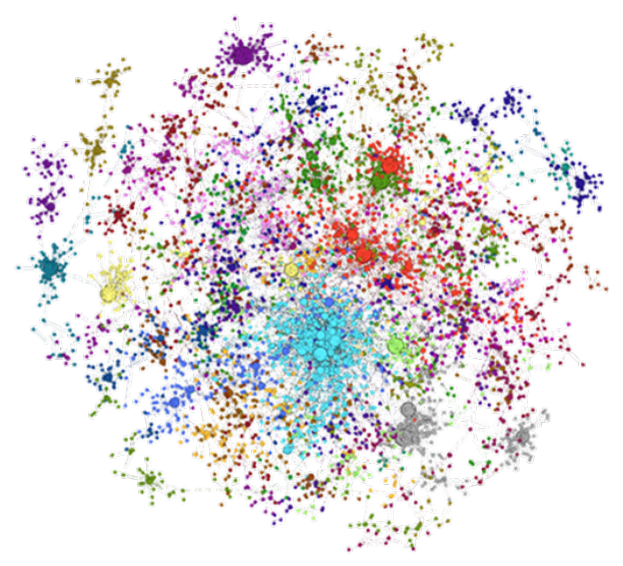

(b)

Fig. 6. (a) GVP original citation networks and (b) GVP giant component citation network

Table 4 - Citation network statistics and main GVP clusters

\begin{tabular}{|c|c|c|c|c|c|c|c|c|c|c|}
\hline \multirow{2}{*}{ Cluster } & \multicolumn{2}{|c|}{ Nodes } & \multicolumn{2}{|c|}{ Edges } & \multirow{2}{*}{ AWD } & \multirow{2}{*}{ CC } & \multirow{2}{*}{ BC } & \multirow{2}{*}{ EVC } & \multirow{2}{*}{ EB } & SS \\
\cline { 2 - 10 } & $\mathbf{N}$ & $\mathbf{\%}$ & $\mathbf{N}$ & $\mathbf{\%}$ & & & & & & \\
\hline Light blue & 461 & $6.81 \%$ & 1149 & $14.26 \%$ & 2.492 & 2.274 & 5,711 & 0.04079 & 16,075 & $\mathbf{5}$ \\
\hline Red & 424 & $6.27 \%$ & 534 & $6.63 \%$ & 1.259 & 1.588 & 982 & 0.04232 & 1,665 & $\mathbf{5}$ \\
\hline Grey & 247 & $3.65 \%$ & 261 & $3.24 \%$ & 1.057 & 1.000 & 261 & 0 & 261 & 1 \\
\hline Pink & 244 & $3.61 \%$ & 275 & $3.41 \%$ & 1.127 & 1.377 & 392 & 0.04383 & 540 & $\mathbf{5}$ \\
\hline Blue & 234 & $3.46 \%$ & 265 & $3.29 \%$ & 1.132 & 1.169 & 319 & 0.04451 & 373 & 4 \\
\hline Yellow & 181 & $2.68 \%$ & 183 & $2.27 \%$ & 1.011 & 1.000 & 183 & 0 & 183 & 0 \\
\hline Light green & 147 & $2.17 \%$ & 148 & $1.84 \%$ & 1.007 & 1.075 & 160 & 0.05233 & 172 & 1 \\
\hline Purple & 144 & $2.13 \%$ & 149 & $1.85 \%$ & 1.035 & 1.333 & 213 & 0.03818 & 284 & 1 \\
\hline Orange & 142 & $2.10 \%$ & 149 & $1.85 \%$ & 1.049 & 1.504 & 256 & 0.03328 & 385 & 3 \\
\hline Brown & 137 & $2.03 \%$ & 142 & $1.76 \%$ & 1.036 & 1.072 & 153 & 0.03343 & 164 & 0 \\
\hline $\begin{array}{c}\text { Giant } \\
\text { Component }\end{array}$ & 5,011 & $74.1 \%$ & 6,519 & $80.9 \%$ & 1.301 & 2.516 & 25,311 & 0.17563 & 71,245 & - \\
\hline $\begin{array}{c}\text { Original } \\
\text { Network }\end{array}$ & 6,765 & $100 \%$ & 8,059 & $100 \%$ & 1.191 & 2.428 & 26,940 & 0.21073 & 72,971 & - \\
\hline
\end{tabular}

Legend: $\mathrm{N}=$ amount; $\mathrm{AWD}=$ Average Weighted Degree; $\mathrm{CC}=\mathrm{Closeness}$ Centrality; $\mathrm{BC}=$ Betweeness Centrality; $\mathrm{EVC}=$ EigenVector Centrality; $\mathrm{EB}=$ Edge Betweenness; $\mathrm{SS}=$ highest statistics score

\subsection{GVP technological routes and most promising and emerging technologies}

Based on three most relevant clusters of citation network, this section shows technological routes (TR) of GVP technologies development, as well as the most promising and emerging technologies (MPET). The routes were built from the subnet of each cluster. After, the SPLC algorithm was applied and identified the RT of that cluster as well as the most promising and emerging patents (Porto, Kannebley and Baroni, 2014; Pereira and Porto, 2018). Next, it will 
be better described TR, MPET and main features identified for three most relevant GVP clusters.

From the cluster "Light blue", this TR consists of 26 patents, $69 \%$ of which are applied and prioritized in USA (figure 7). In this TR, there is a predominance of American and Japanese patents, as a general feature in this cluster. Another characteristic of this TR is that only 4 patents have firms as assignees, being strongly influenced by independent researchers. Only $15.4 \%$ patents have more than one assignee, which leads to conclusion that co-ownership does not express relevant evidence of cooperation for this TR. Regarding market protection, it is observed that $88,4 \%$ of patents have protection only in the first application country. This TR initializes with technologies on generating system for an electric vehicle, battery charging system for electric vehicles and self-charging electrical car with wind energy recovery system that culminated in the two MPET: hybrid vehicle with multiple energy sub-systems (US9428061B1) and machine with a self-powering device (WO2014020437A1). MPET1 was deposited at three different IPC (B60L000800, H02J000700 and H02J000714), indicating greater chances of use in other fields. While, MPET2 was categorized exclusively in the IPC B60L000800, which proves to be a well-targeted technology for GVP.
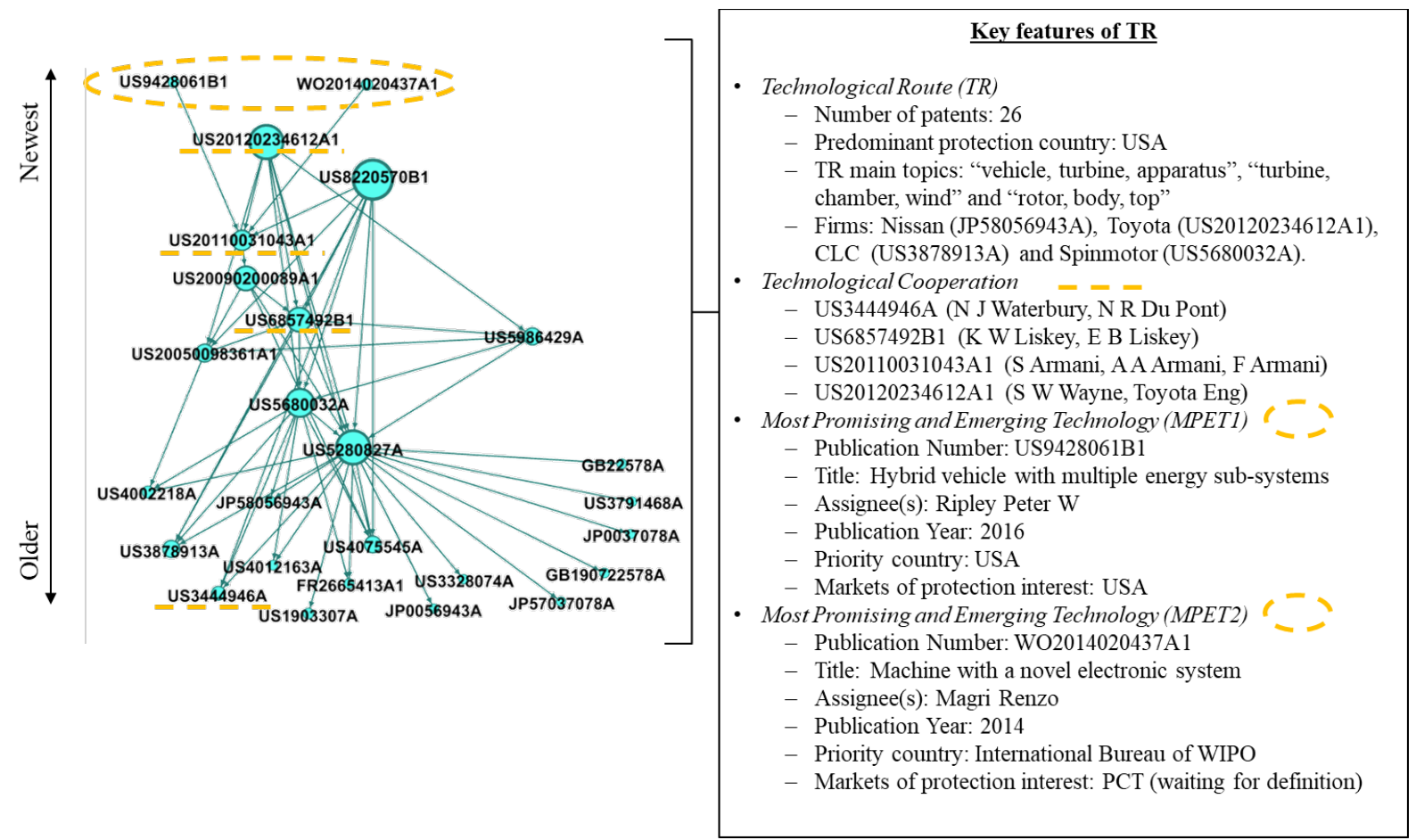

Fig. 7. Key features of Light blue TR

The second TR was obtained from "Red cluster" which 92\% of patents were applied in the USA and $8 \%$ in Japan (figure 8). Unlike Light blue, patents of TR Red have a broader protection concern, with 18 patents with protection beyond the first application country with major relevance to Germany, Japan and EPO markets (in addition to USA market). This TR have 21\% of co-ownership which characterizes the option for cooperation for development of GVP technologies in this route. Evolution of this TR begins with technologies about automobile with solar battery, thermal insulating shade, motor vehicle roof with outside solar generator, solar electric vehicle with foldable body panels on a sun tracking chassis that resulted in group of systems for making solar electric vehicle more practical (US20140297072A1). This MPET addresses a car integrated with deployable solar panel arrays which were firmly affixed in the undeployed configuration to permit highway travel so as withstand wind. It covers technological domains about electric propulsion and PV cell arrays. 

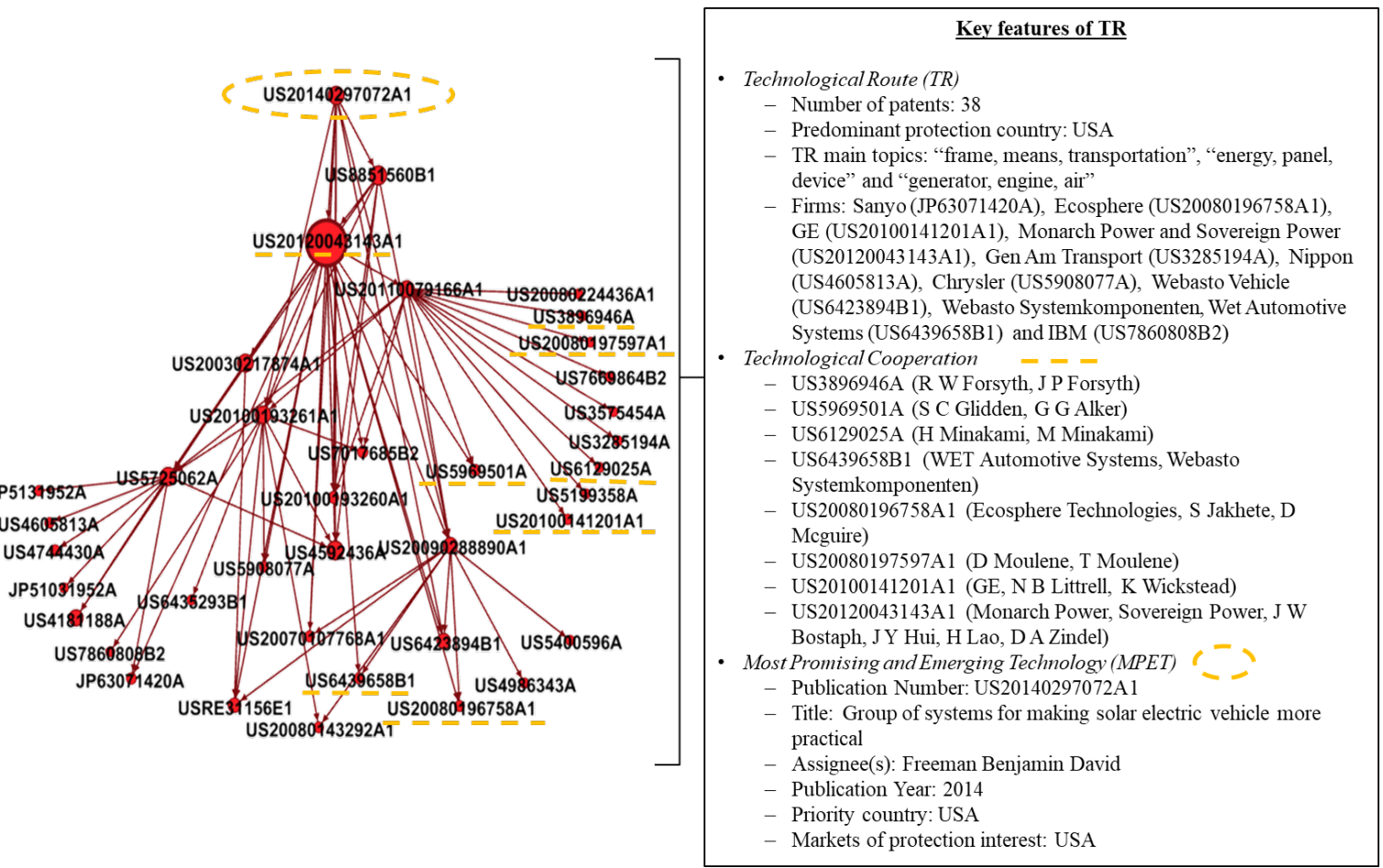

Fig. 8. Key features of Red TR

The TR "Pink" has 94\% applied and prioritized in China (figure 9), indicating an absolute predominance of protection for this market. Unlike other clusters, in this route there are patents developed by universities and research centers, as well as companies interested in GVP technologies. However, there is a preference for the development of proprietary technology by companies, which use their $R \& D$ as a priority. There is in this route a preference for the exclusive technological development of $R \& D$ because just one patent is involved in cooperation. Initial trajectory of this TR starts with technologies based on wind solar energy combined power electric car and multi-motor driving structure of electric car, pass through wind energy and solar energy complementary electric automobile and multi-energy electric vehicle until culminate in three different MPET: recreational vehicle electrical assembly system (CN104709100A), an electric car with wind power generation device (CN105015349A) and wind power charging device which comprises a pneumatic device, an electric generator, a battery, a controller, an inverter and a motor (CN105083032A). 


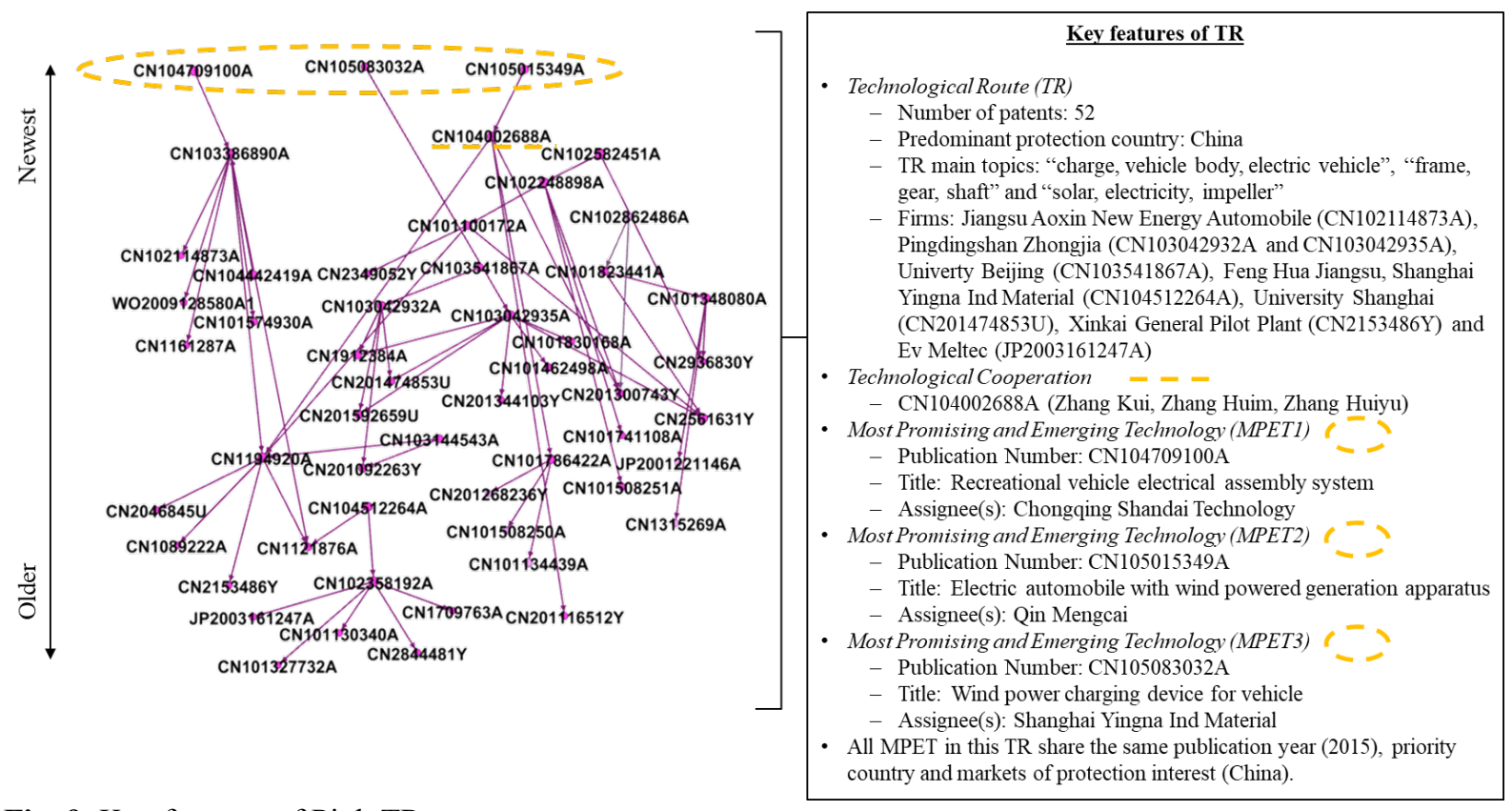

Fig. 9. Key features of Pink TR

\section{Conclusions}

This paper analyzed inventions on vehicle propulsion systems provided by solar or wind energy. The findings address three main groups: emerging technologies, countries of interest for market protection, and competitiveness and behavior of three groups of GVP developers: long term, recent, and occasional innovators.

In each TR, the GVP main emerging technologies were pointed out. Then, the MPETs were identified in each technological route. The concept of MPET is our first theoretical contribution. It expands the notion of emerging technology to its ability to create impact on the market in addition to its recency. By analyzing each MEPTs and their technological route, we found that the flow of technological knowledge in each route tends to be concentrated in patents developed in the same country and the predominant interest of protection happens in the country that technology was firstly applied. We also found a strong presence of independent assignees (individuals) and a lack of collaborative R\&D (i.e. joint patent applications). Despite of benefits of business internationalization and globalization (Waheeduzzaman et al., 2011; Hsu et al., 2015; Borda et al., 2017; Coulibaly et al. 2018), the incentives for the development of green technologies (Nesta et al., 2014; Romano et al., 2017) and, the advent of open innovation (Chesbrough and Appleyard, 2007; West et al., 2014), the findings concluded that organizations tend to be conservative when it comes to protecting their technologies. They are closed to R\&D partnerships in this area and choose markets where they already know or dominate.

Regarding the interest countries to market protection, Asian countries dominate patent applications, with China accounting for $66.3 \%$ of all GVP patents. Despite this, China has been a follower in this segment with $74.4 \%$ of its patents applied after 2010 . From perspective of GVP inventions volume, Chinese relevance reflects its policies to foster technological innovation as well as its interest in technologies related to EV and HEV. However, China has not been pointed out in previous studies by Rajashekara (2013) and El-Refaie (2013), which indicate Japanese and American companies as the most relevant in this area. In fact, Bohnsack (2018) highlight that China's efforts on electric vehicles dates back from the $8^{\text {th }}$ year plan (19811985) period - which gives an indication for the time need to move from investment to become a relevant player in the development intellectual property. In addition, on application countries, 
GVP patents are generally protected priority in their developing countries which main markets of protection interest are China, Germany, the European Patent Office, Japan and the USA. In addition, the assignees who first deposit a patent in Asian countries have a preferential interest in the domestic market itself. Patents that were firstly applied in the European Patent Office have interest in technology protection in European Patent Office, USA and Japan. In addition, patents applied in the USA and Canada, are also protected in Japan, European Patent Office and China, beyond their own markets. It can be concluded that the first application country is equivalent to the principal market of protection interest to GVP technologies' assignees.

From the point of view of business competitiveness and behavior GVP developers, Toyota, Hyundai, Honda, Nissan, Ford Global Tech and GM Global beyond relevance and frequency of patent applications may be considered as "Long term innovators". Peugeot Citroen, Jiangsu University, Pingdingshan Zhongjia and Kunming University are considered "Occasional innovator" because they have not kept regular applications over the years. Chinese firms Wuxi Tongchun, Chongqing Yongchun, Tianjin Coslight, Huzhou Chari, Wuxi New Great are considered "Recent innovator". It is worth mentioning there are also many independent assignees (individuals) in the network. These assignees, most of which are also patent inventors too, may be hired indirectly by interested companies or may be just experts working on GVP technologies for later commercialization. It should be noted that the patent authorities of each country, have different levels of effectiveness which leads to very different time frames for the analysis and granting of patents. In most cases, the USPTO is the office with the fastest review process, followed by the EPO. Thus, it is possible that some assignees choose to deposit initially in offices whose process of analysis is faster, in order to guarantee the formalization of the legal guarantee of exclusivity in the shortest possible period. On the other hand, there are situations where assignees are restricted to protection only in their own market. This decision may be due to a number of situations, from the absorption capacity of the protected technology to the extent of potential consumer markets, and to low expectations regarding the degree of disruption of the protected invention. Thus, this is a topic for future studies, in which we intend to analyze whether the effectiveness of the process of analysis and grant of patents interferes in the strategic decision of the assignees to choose the first country of deposit.

Based on the conclusions above, the contributions of this paper can be summarized in both theoretical and practical domains. Theoretical contributions include:

(i) The use of patent-based technological routes is shown to be a robust tool to investigate the evolution of a technological domain, allowing analysis from the base technologies to the identification of the most emerging and promising ones;

(ii) The proposed classification (long-term, recent, and occasional innovators) for assignees is a theoretical contribution. The classification will need to be applied to other technological fields and improved further.

(iii) TRs identified in this study denote a non-collaborative development and protection profile for GVP technologies implying that companies prefer to solo development or acquire it from independent researchers instead of joint $R \& D$ and consequent patent application.

(iv) The major players in automobile industry have their share in GVP technologies development, but they seem to tend more to acquire such technologies through independent researchers. It is possible that this is a consolidation of industry convergence (Sick et al, 2019) is taking place (e.g. solar and wind energy, electric batteries and automotive powertrains).

The development of GVP is currently in the growth phase. There are opportunities for companies and independent inventors and this paper can help them in key technologies, players, and markets for protection. Thus, the paper provides the following practical contributions: 
(i) GVP technological background are more concentrated in USA, China, Japan and Germany patents offices - so it is possible that national factors are key drivers for the development of these technologies;

(ii) Asian inventors, especially Chinese, should be carefully observed. While the growth of China in green technology may sound obvious due to energy security and pollution reduction, they did not appear in earlier similar studies (Wesseling et al, 2015);

(iii) The diffusion of emerging technologies presented in this study seeks to support R\&D areas in their decisions about GVP fields, offering data of most relevant technologies, their owners, relationships, as well as their marketing protection coverage through reliable and replicable metrics;

(iv) Through analysis of GVP technological routes, industry experts can observe in a simplified way that is followed and adopted by scientists and market;

One limitation of this study is that patents remain for 18 months without disclosure of their information (period of secrecy), due to international legislation. Thus, some data are not available for analysis and these patents cannot be considered in the analysis.

Future studies may focus on technological cooperation and add other IPCs related to vehicle propulsion, including. Thus, complementary insights can be achieved and that could enrich the literature of technological innovation and forecasting in GVP systems. Considering an analysis that goes beyond the IPC-GI classifications, future studies could also apply search queries using GVP keywords in order to expand the horizon of GVP patents to be analyzed.

\section{Acknowledgments}

The authors are grateful to financial support of FAPESP - São Paulo Research Foundation (2012/22686-9) and CAPES Foundation (PDSE/88881.132723/2016-01).

\section{References}

Altuntas, S., Dereli, T., Kusiak, A., 2015. Forecasting technology success based on patent data. Technological Forecasting and Social Change, 96, 202-214. https://doi.org/10.1016/j.techfore.2015.03.011

Ardito, L., D'Adda, D., Petruzzelli, A. M., 2018. Mapping innovation dynamics in the Internet of Things domain: Evidence from patent analysis. Technological Forecasting and Social Change, 136, 317-330. https://doi.org/10.1016/j.techfore.2017.04.022

Bastian, M., Heymann, S., Jacomy, M., 2009. Gephi: an open source software for exploring and manipulating networks. ICWSM, 8, 361-362.

Batagelj, V., Cerinšek, M., 2013. On bibliographic networks. Scientometrics, 96(3), 845-864. https://doi.org/10.1007/s11192-012-0940-1

Bekkers, R., Martinelli, A., 2012. Knowledge positions in high-tech markets: Trajectories, standards, strategies and true innovators. Technological Forecasting and Social Change, 79(7), 1192-1216. https://doi.org/10.1016/j.techfore.2012.01.009

Blackman, M., 1995. Provision of patent information: a national patent office perspective. World Patent Information, 17(2), 115-123. https://doi.org/10.1016/0172-2190(95)00012-O

Blondel, V.D., Guillaume, J. L., Lambiotte, R., Lefebvre, E., 2008. Fast unfolding of communities in large networks. Journal of statistical mechanics: theory and experiment, 2008(10), P10008. https://doi.org/10.1088/1742-5468/2008/10/P10008

Bloomberg, 2016. Bloomberg New Energy Finance. New Energy Outlook (NEO). 
Bohnsack, R. (2018). Local niches and firm responses in sustainability transitions: The case of low-emission vehicles in China. Technovation, 70, 20-32. https://doi.org/10.1016/j.technovation.2018.02.002

Borda, A., Geleilate, J. M. G., Newburry, W., Kundu, S. K., 2017. Firm internationalization, business group diversification and firm performance: The case of Latin American firms. Journal of Business Research, 72, 104-113. https://doi.org/10.1016/j.jbusres.2016.11.006

Brandes, U., 2001. A faster algorithm for betweenness centrality. Journal of mathematical sociology, 25(2), 163-177. https://doi.org/10.1080/0022250X.2001.9990249

Bruck, P., Réthy, I., Szente, J., Tobochnik, J., Érdi, P., 2016. Recognition of emerging technology trends: class-selective study of citations in the US Patent Citation Network. Scientometrics, 107(3), 1465-1475. https://doi.org/10.1007/s11192-016-1899-0

Burch, I., Gilchrist, J., 2018. Survey of global activity to phase out internal combustion engine vehicles. Center of Climate Protection: Santa Rosa, CA, USA.

Burhan, M., Singh, A. K., Jain, S. K., 2017. Patents as proxy for measuring innovations: A case of changing patent filing behavior in Indian public funded research organizations. Technological Forecasting and Social Change, 123, 181-190. https://doi.org/10.1016/j.techfore.2016.04.002

Campbell, R.S., 1983. Patent trends as a technological forecasting tool. World Patent Information, 5(3), 137-143. https://doi.org/10.1016/0172-2190 (83)90134-5

Chan, C.C., 1993. Present status and future trends of electric vehicles. In Advances in Power System Control, Operation and Management, 1993. APSCOM-93., 2nd International Conference on (pp. 456-469). IET.

Chan, C.C., 2007. The state of the art of electric, hybrid, and fuel cell vehicles. Proceedings of the IEEE, 95(4), 704-718. https://doi.org/10.1109/JPROC.2007.892489

Chen, A., Yang, H., Lo, H.K., Tang, W.H., 2002. Capacity reliability of a road network: an assessment methodology and numerical results. Transportation Research Part B: Methodological, 36(3), 225-252. https://doi.org/10.1016/S0191-2615(00)00048-5

Chesbrough, H. W., Appleyard, M. M., 2007. Open innovation and strategy. California management review, 50(1), 57-76. https://doi.org/10.2307/41166416

Choi, C., Kim, S., Park, Y., 2007. A patent-based cross impact analysis for quantitative estimation of technological impact: The case of information and communication technology. Technological Forecasting and Social Change, 74(8), 1296-1314. https://doi.org/10.1016/j.techfore.2006.10.008

Coulibaly, S. K., Erbao, C., Mekongcho, T. M., 2018. Economic globalization, entrepreneurship, and development. Technological Forecasting and Social Change, 127, 271-280. https://doi.org/10.1016/j.techfore.2017.09.028

Cozzens, S., Gatchair, S., Kang, J., Kim, K. S., Lee, H. J., Ordóñez, G., Porter, A., 2010. Emerging technologies: quantitative identification and measurement. Technology Analysis \& Strategic Management, 22(3), 361-376. https://doi.org/10.1080/09537321003647396

Creutzig, F., Jochem, P., Edelenbosch, O.Y., Mattauch, L., van Vuuren, D.P., McCollum, D., Minx, J., 2015. Transport: A roadblock to climate change mitigation?. Science, 350(6263), 911-912. https://doi.org/10.1126/science.aac8033

Egghe, L., Rousseau, R., 2002. Co-citation, bibliographic coupling and a characterization of lattice citation networks. Scientometrics, 55(3), 349-361. https://doi.org/10.1023/A:1020458612014 
El-Refaie, A.M., 2013. Motors/generators for traction/propulsion applications: A review. IEEE Vehicular Technology Magazine, 8(1), 90-99. https://doi.org/10.1109/IEMDC.2011.5994647

Eilers, K., Frischkorn, J., Eppinger, E., Walter, L., \& Moehrle, M. G. (2019). Patent-based semantic measurement of one-way and two-way technology convergence: The case of ultraviolet light emitting diodes (UV-LEDs). Technological Forecasting and Social Change, 140, 341-353. https://doi.org/10.1016/j.techfore.2018.12.024

Fontana, R., Nuvolari, A., Verspagen, B., 2009. Mapping technological trajectories as patent citation networks. An application to data communication standards. Economics of Innovation and New Technology, 18(4), 311-336. https://doi.org/10.1080/10438590801969073

Gielen, D., Boshell, F., Saygin, D., Bazilian, M. D., Wagner, N., Gorini, R., 2019. The role of renewable energy in the global energy transformation. Energy Strategy Reviews, 24, 38-50. https://doi.org/10.1016/j.esr.2019.01.006

Hau, E., 2013. Wind turbines: fundamentals, technologies, application, economics. Springer Science \& Business Media. https://doi.org/10.1007/3-540-29284-5

Haupt, R., Kloyer, M., Lange, M., 2007. Patent indicators for the technology life cycle development. Research Policy, 36(3), 387-398. https://doi.org/10.1016/j.respol.2006.12.004

Hille, E., Althammer, W., Diederich, H., 2020. Environmental regulation and innovation in renewable energy technologies: Does the policy instrument matter?. Technological Forecasting and Social Change, 153. https://doi.org/10.1016/j.techfore.2020.119921

Hsu, C. W., Lien, Y. C., Chen, H., 2015. R\&D internationalization and innovation performance. International Business Review, 24(2), 187-195. https://doi.org/10.1016/j.ibusrev.2014.07.007

Hochstetler, K., Kostka, G., 2015. Wind and solar power in Brazil and China: interests, statebusiness relations, and policy outcomes. Global Environmental Politics. https://doi.org/10.1162/GLEP_a_00312

Høyer, K.G., 2008. The history of alternative fuels in transportation: The case of electric and hybrid cars. Utilities Policy, 16(2), 63-71. https://doi.org/10.1016/j.jup.2007.11.001

Hummon, N.P., Dereian, P., 1989. Connectivity in a citation network: The development of DNA theory. Social networks, 11(1), 39-63. https://doi.org/10.1016/0378-8733(89)90017-8

Hussain, A., Arif, S.M., Aslam, M., 2017. Emerging renewable and sustainable energy technologies: State of the art. Renewable and Sustainable Energy Reviews, 71, 12-28. https://doi.org/10.1016/j.rser.2016.12.033

IEA, 2016a. Medium-Term Renewable Energy Market Report 2016, OECD/IEA, Paris.

IEA, 2016b. Next Generation Wind and Solar Power - From Cost to Value, OECD/IEA, Paris.

IEA, 2018. Perspectives for the Energy Transition: The Role of Energy Efficiency, OECD/IEA, Paris.

IEA, 2019. Global EV Outlook 2019. Scaling up the transition to electric mobility, IEA, Paris. https://www.iea.org/reports/global-ev-outlook-2019

IPCC, 2014. Climate Change 2014: Mitigation of Climate Change. Cambridge University Press, Cambridge, United Kingdom; New York, NY, USA.

ITF, 2017. ITF Transport Outlook 2017, OECD Publishing, Paris. http://dx.doi.org/10.1787/9789282108000-en

Johnston, B., Mayo, M. C., \& Khare, A. (2005). Hydrogen: the energy source for the 21st century. Technovation, 25(6), 569-585. https://doi.org/10.1016/j.technovation.2003.11.005 
Keeling, M.J., Eames, K.T., 2005. Networks and epidemic models. Journal of the Royal Society Interface, 2(4), 295-307. https://doi.org/10.1098/rsif.2005.0051

Kempton, W., Tomić, J., 2005. Vehicle-to-grid power implementation: From stabilizing the grid to supporting large-scale renewable energy. Journal of power sources, 144(1), 280-294. https://doi.org/10.1016/j.jpowsour.2004.12.022

Kim, K., Kim, Y., 2015. Role of policy in innovation and international trade of renewable energy technology: Empirical study of solar PV and wind power technology. Renewable and Sustainable Energy Reviews, 44, 717-727. https://doi.org/10.1016/j.rser.2015.01.033

Kim, C., Lee, H., Seol, H. Lee, C., 2011. Identifying core technologies based on technological cross-impacts: An association rule mining (ARM) and analytic network process (ANP) approach. Expert Systems with Applications, Volume 38, p. 12559-12564. https://doi.org/10.1016/j.eswa.2011.04.042

Kittner, N., Tsiropoulos, I., Tarvydas, D., Schmidt, O., Staffell, I., Kammen, D. M., 2020z. Electric vehicles. Technological Learning in the Transition to a Low-Carbon Energy System (pp. 145-163). Academic Press.

Kumar, L., Jain, S., 2014. Electric propulsion system for electric vehicular technology: A review. Renewable and Sustainable Energy Reviews, 29, 924-940. https://doi.org/10.1016/j.rser.2013.09.014

Kuhn, T. S., 2012. The structure of scientific revolutions. University of Chicago press.

Lee, J., Berente, N., 2013. The era of incremental change in the technology innovation life cycle: An analysis of the automotive emission control industry. Research Policy, 42(8), 1469-1481. https://doi.org/10.1016/j.respol.2013.05.004

Li, Y., Zhan, C., de Jong, M., Lukszo, Z., 2016. Business innovation and government regulation for the promotion of electric vehicle use: lessons from Shenzhen, China. Journal of Cleaner Production, 134, 371-383. https://doi.org/10.1016/j.jclepro.2015.10.013

Liu, W., Lund, H., Mathiesen, B. V., 2011. Large-scale integration of wind power into the existing Chinese energy system. Energy, 36(8), 4753-4760. https://doi.org/10.1016/j.energy.2011.05.007

Lund, H., Kempton, W., 2008. Integration of renewable energy into the transport and electricity $\begin{array}{llll}\text { sectors through } & \text { V2G. Energy policy, 36(9), 3578-3587. }\end{array}$ https://doi.org/10.1016/j.enpol.2008.06.007

Martinelli, A., 2008. Technological trajectories and industry evolution: the case of telecom switching industry. In Proceedings of the CESPRI seminar, Bocconi University Italy, 26-32008 Milan.

Miller, J. M., 2008. Trends in vehicle energy storage systems: Batteries and ultracapacitors to unite. In Vehicle Power and Propulsion Conference, 2008. VPPC'08. IEEE (pp. 1-9). IEEE. https://doi.org/10.1109/VPPC.2008.4685980

Momeni, A., Rost, K., 2016. Identification and monitoring of possible disruptive technologies by patent-development paths and topic modeling. Technological Forecasting and Social Change, 104, 16-29. https://doi.org/10.1016/j.techfore.2015.12.003

Nema, P., Nema, R.K., Rangnekar, S., 2009. A current and future state of art development of hybrid energy system using wind and PV-solar: A review. Renewable and Sustainable Energy Reviews, 13(8), 2096-2103. https://doi.org/10.1016/j.rser.2008.10.006

Nesta, L., Vona, F., Nicolli, F., 2014. Environmental policies, competition and innovation in renewable energy. Journal of Environmental Economics and Management, 67(3), 396-411. https://doi.org/10.1016/j.jeem.2014.01.001 
Newman, M., 2010. Networks: an introduction. Oxford University Press. https://doi.org/10.1162/artl_r_00062

OECD, 1994. Using Patent Data as Science and Technology Indicators. Patent Manual, OECD GD.

OECD, 2018. Guidelines for collecting and interpreting innovation data. Oslo Manual, Paris OECD.

Patel, M.R., 2005. Wind and solar power systems: design, analysis, and operation. CRC press. https://doi.org/10.1260/030952406778606197

Patterson, M., Macia, N.F., Kannan, A.M., 2015. Hybrid microgrid model based on solar photovoltaic battery fuel cell system for intermittent load applications. IEEE Transactions on Energy Conversion, 30(1), 359-366. https://doi.org/10.1109/TEC.2014.2352554

Pereira C.G., Porto G.S., 2018. Uncovering Innovation Features and Emerging Technologies in Molecular Biology through Patent Analysis. In: Picanço-Castro V., Swiech K. (eds) Recombinant Glycoprotein Production. Methods in Molecular Biology, vol 1674, pp. 15-34. Humana Press, New York, NY. https://doi.org/10.1007/978-1-4939-7312-5_2

Pereira, C. et al., 2018. Patent mining and landscaping of emerging recombinant factor VIII through network analysis. Nat Biotechnol, 36, 585-590. https://doi.org/10.1038/nbt.4178

Pereira, C. G., Lavoie, J. R., Garces, E., Basso, F., Dabić, M., Porto, G. S., Daim, T., 2019. Forecasting of emerging therapeutic monoclonal antibodies patents based on a decision model. Technological Forecasting and Social Change, 139, 185-199. https://doi.org/10.1016/j.techfore.2018.11.002

Porto, G.S.; Kannebley Jr., S.; Baroni, J., 2014. Análise das Rotas Tecnológicas com Base no Levantamento dos Grupos de Patentes Verdes. In. Toneto Jr. R. Pinho, M. (Coordenadores) Economia de baixo carbono: impactos de novos marcos regulatórios e tecnologias sobre a economia brasileira. Ribeirão Preto, SP. FUNPEC Editora.

Prabhakaran, T., Lathabai, H.H., Changat, M., 2015. Detection of paradigm shifts and emerging fields using scientific network: A case study of Information Technology for Engineering. Technological Forecasting and Social Change, 91, 124-145. https://doi.org/10.1016/j.techfore.2014.02.003

Rajashekara, K., 2013. Present status and future trends in electric vehicle propulsion technologies. IEEE Journal of Emerging and Selected Topics in Power Electronics, 1(1), 310. https://doi.org/10.1109/JESTPE.2013.2259614

Richardson, D.B., 2013. Electric vehicles and the electric grid: A review of modeling approaches, Impacts, and renewable energy integration. Renewable and Sustainable Energy Reviews, 19, 247-254. https://doi.org/10.1016/j.rser.2012.11.042

Rogers, E.M., 2010. Diffusion of innovations. Simon and Schuster.

Romano, A. A., Scandurra, G., Carfora, A., Fodor, M., 2017. Renewable investments: The impact of green policies in developing and developed countries. Renewable and Sustainable Energy Reviews, 68, 738-747. https://doi.org/10.1016/j.rser.2016.10.024

Rotolo, D., Hicks, D., Martin, B.R., 2015. What is an emerging technology? Research Policy, 44(10), 1827-1843. https://doi.org/10.1016/j.respol.2015.06.006

Sick, N., Preschitschek, N., Leker, J., Bröring, S. (2018). A new framework to assess industry convergence in high technology environments. Technovation. (In Press). https://doi.org/10.1016/j.technovation.2018.08.001

Scott, J., 2017. Social network analysis. Sage.

Sims R. et al., 2014. Climate Change 2014: Mitigation of Climate Change. Contribution of Working Group III to the Fifth Assessment Report of the Intergovernmental Panel on 
Climate Change. Cambridge University Press, Cambridge, United Kingdom and New York, NY, USA.

Solangi, K.H., Islam, M.R., Saidur, R., Rahim, N.A., Fayaz, H., 2011. A review on global solar energy policy. Renewable and sustainable energy reviews, 15(4), 2149-2163. https://doi.org/10.1016/j.rser.2011.01.007

Song, K., Kim, K., Lee, S., 2018. Identifying promising technologies using patents: A retrospective feature analysis and a prospective needs analysis on outlier patents. Technological Forecasting and Social Change, 128, 118-132. https://doi.org/10.1016/j.techfore.2017.11.008

UNFCCC, 2015. Adoption of the Paris Agreement. United Nations Framework Convention on Climate Change, Paris, https://unfccc.int/resource/docs/2015/cop21/eng/109r01.pdf .

Verborgh, R., De Wilde, M., 2013. Using OpenRefine. Packt Publishing Ltd.

Verspagen, B., 2007. Mapping technological trajectories as patent citation networks: A study on the history of fuel cell research. Advances in Complex Systems, 10(01), 93-115. https://doi.org/10.1142/S0219525907000945

Waheeduzzaman, A. N. M., Chang, J., 2011. The early and rapid internationalization of Asian emerging MNEs. Competitiveness Review: An International Business Journal. https://doi.org/10.1108/10595421111117452

Wang, J., Liu, C., Ton, D., Zhou, Y., Kim, J., Vyas, A., 2011. Impact of plug-in hybrid electric vehicles on power systems with demand response and wind power. Energy Policy, 39(7), 4016-4021. https://doi.org/10.1016/j.enpol.2011.01.042

Wang, T., Yu, H., Zhu, C., 2008. Hybrid energy sources for hybrid electric vehicle propulsion. In Vehicle Power and Propulsion Conference, 2008. VPPC'08. IEEE (pp. 1-4). IEEE. https://doi.org/10.1109/VPPC.2008.4677787

Wesseling, J. H., Niesten, E. M. M. I., Faber, J., \& Hekkert, M. P., 2015. Business strategies of incumbents in the market for electric vehicles: Opportunities and incentives for sustainable innovation. Business Strategy and the Environment, 24(6), 518-531. https://doi.org/10.1002/bse.1834

West, J., Salter, A., Vanhaverbeke, W., Chesbrough, H., 2014. Open innovation: The next decade. Research Policy, 43(5), 805-811. https://doi.org/10.1016/j.respol.2014.03.001

Williamson, S.S., Rathore, A.K., Musavi, F., 2015. Industrial electronics for electric transportation: Current state-of-the-art and future challenges. IEEE Transactions on Industrial Electronics, 62(5), 3021-3032. https://doi.org/ 10.1109/TIE.2015.2409052

WIPO, 2017. International Patent Classification (IPC) - Official Publication, $<$ http://www.wipo.int/classifications/ipc/en/>.

Wu, Y. et al., 2017. On-road vehicle emissions and their control in China: A review and outlook. Science of the Total Environment, 534, 332-349. https://doi.org/10.1016/j.scitotenv.2016.09.040

Yong, J.Y., Ramachandaramurthy, V.K., Tan, K.M., Mithulananthan, N., 2015. A review on the state-of-the-art technologies of electric vehicle, its impacts and prospects. Renewable and Sustainable Energy Reviews, 49, 365-385. https://doi.org/10.1016/j.rser.2015.04.130

Yu, H., Wei, Y.M., Tang, B.J., Mi, Z., Pan, S.Y., 2016. Assessment on the research trend of low-carbon energy technology investment: A bibliometric analysis. Applied Energy, 184, 960-970. https://doi.org/10.1016/j.apenergy.2016.07.129

Zhang, M., 2010. Social network analysis: history, concepts, and research. In Handbook of social network technologies and applications (pp. 3-21). Springer, Boston, MA. https://doi.org/10.1007/978-1-4419-7142-5_1 
Zhang, F., Gallagher, K. S., 2016. Innovation and technology transfer through global value chains: Evidence from China's PV industry. Energy Policy, 94, 191-203. https://doi.org/10.1016/j.enpol.2016.04.014

Zheng, B., Zhang, Q., Borken-Kleefeld, J., Huo, H., Guan, D., Klimont, Z., He, K., 2015. How will greenhouse gas emissions from motor vehicles be constrained in China around 2030? Applied Energy, 156, 230-240. https://doi.org/10.1016/j.apenergy.2015.07.018

Zhou, W., Lou, C., Li, Z., Lu, L., Yang, H., 2010. Current status of research on optimum sizing of stand-alone hybrid solar-wind power generation systems. Applied Energy, 87(2), 380389. https://doi.org/10.1016/j.apenergy.2009.08.012 